\title{
Graphic Design Students' Perspectives and Job Anxiety About Distance Education in the Pandemic Period
}

\author{
Sevtap Kanat ${ }^{1}$ \\ ${ }^{1}$ Grafik Tasarım Bölümü, Güzel Sanatlar ve Tasarım Fakültesi, Dr. Öğr. Üyesi, İnönü Üniversitesi, Turkey \\ Correspondence: Sevtap Kanat, Grafik Tasarım Bölümü, Güzel Sanatlar ve Tasarım Fakültesi, Dr. Öğr. Üyesi, \\ İnönü Üniversitesi, Malatya, Turkey. E-mail: sevtap.kanat@inonu.edu.tr
}

Received: May 30, 2021

Accepted: August 24, 2021

Online Published: November 24, 2021

doi:10.5539/ies.v14n12p40

URL: https://doi.org/10.5539/ies.v14n12p40

\begin{abstract}
The coronavirus emerging in China has rapidly become a global epidemic. Many sanctions come to the fore to prevent the spread of the epidemic. One of them is that people stay at home and do not leave the house unless it is necessary. This necessity has affected the education system as in all areas of life. Universities have switched to the distance education system. Unfortunately, many universities do not have sufficient infrastructure or resources to facilitate instantly effective online teaching. In this study, it was aimed to determine the problems faced by the graphic design department students during the distance education process conducted during the Covid-19 pandemic period, their opinions on distance education and their job anxiety levels. This study is important in terms of determining the level of job anxiety faced by graphic designer candidates during their education, taking necessary precautions, supporting them in eliminating these concerns, raising their awareness on the subject and making determinations to reduce job anxiety. It is important to know the thoughts of students towards distance education especially during the pandemic period in order to increase the quality of education. The sample of the research consists of students studying in the field of graphic design in the 2020-2021 academic year in Turkey. The stratified sampling method was used in sample selection. Distance Education Attitude Scale and Job Anxiety Scale were used in the study. The sampling was carried out with the voluntary participation. Research data were collected from Google Forms through a questionnaire consists of personal information and the scales. SPSS 21 (Statistical Package for the Social Sciences) statistical software was used for data analysis. The relationship between job anxiety level and distance education satisfaction level is seen that there is almost zero and statistically insignificant. The anxiety score for this group of students is above the average and reasons should be analyze in great detail. On the other hand, distance education attitude score is below the average. The reasons would be related to being unprepared to this period. The most important factor in the occurrence of this situation is being caught unprepared for this process. While job anxiety differed in the level of satisfaction with the program, the distance education attitude differed in the education level of the mother, the education level of the father, grades and the level of satisfaction with the program. Although the relationship between the two scales was not significant in the study, it was observed that the distance education limitation factor was in a negative but weak and significant relationship between all factors of the job anxiety scale.
\end{abstract}

Keywords: pandemic, job anxiety, distance education, COVID-19

\section{Introduction}

Covid-19, which was first detected in Wuhan, China on December 31, 2019, has turned into an epidemic that threatens the whole world in a very short time (Almutairi \& Al-Shamrani, 2020; Bentata, 2020; Çakın \& Akyavuz, 2020; Kurnaz \& Serçemeli, 2020; Sahu, 2020; Wang et al., 2020; Y1lmaz, 2020). In Turkey, the first case was seen in the March 11, 2020 (Health Ministry, 2020). The Covid-19 epidemic, spreading over a very wide geography in a short time, affects people's lives in every aspect and causes change (Karakuş et al., 2020). All countries are trying to take precautions by conducting vaccination studies against this virus. The most important precaution to be taken is that people are socially isolated. Other precautions include not leaving their homes unless they have to, adhering to hygiene rules, paying attention to masks and social distance. Different methods and applications have been developed to keep up with this new world. For example, during the epidemic period, shopping is done over a phone application and the products are left in customers through couriers.

During the pandemic period, education also was negatively affected, like in health, transportation, social and 
economy. The first precaution taken all over the world in terms of education is the closure of schools and a suspension of education. In this period, with the thought that the epidemic would take a long time, it was decided to switch to distance education as the only solution worldwide to ensure that students do not fall into a gap, their learning processes are not interrupted, and education continues (Bentata, 2020; Çakın \& Akyavuz, 2020; Karakuş et al., 2020; Kurnaz \& Serçemeli, 2020; Osman, 2020; Telli \& Altun, 2020; Poultsakis et al., 2021). However, many countries were caught unprepared for distance education. Some majors are given distance education for only a few universities in Turkey. Although common compulsory courses such as English, Turkish Language and Ataturk's Principles and History of Revolution are given through distance education, it was the first time that a wider education was given in all departments and levels.

Unfortunately, many universities do not have sufficient infrastructure or resources to facilitate instantly effective online teaching (Sahu, 2020). The Ministry of Education in Turkey started its distance education using the TRT e-school channel and Education Information Network, EBA (Sar1, 2020). On the other hand, some of the universities have tried to spend this period efficiently by using online synchronous methods, some of them offline asynchronous methods and some of them mixed methods as distance education methods.

Distance education is briefly expressed as educational practices through information and communication technologies that are structured on environments where teacher and student are separated in terms of time and space (İşman, 2008; Seven, 2012; Fidan, 2016; Keskin, 2016; Ülkü, 2018; Bozkurt, 2020).

There are many advantages such as having lecture videos recorded in distance education, such that students can watch these lecture videos whenever they want and are economical (Traxler, 2018). In addition, there are also disadvantages such as the inability to replace face-to-face education, unwilling and compulsory distance education for many people, and lessons being given online. At the same time, the existence of groups with different socioeconomic levels in the society, different digital literacy, and the long-term effects of distance education on students have been discussed (Yiğit et al., 2010). Researchers state that students must have self-efficacy in various fields in order to be successful with distance education (Çakın \& Akyavuz, 2020). The uncertain and difficult process in education causes anxiety in students and parents. For the pandemic period and beyond, uncertainty about the professional future of students, unemployment, anxiety about finding suitable jobs, concerns about the education received and job anxiety arise (Şenses, 2019).

Anxiety is one of the most basic emotions that people are born with, and it is the state of anxiety that occurs at the time of danger (Anthony \& Swinson, 2000; Spielberger \& Reheiser, 2009; Horney, 2014; Karabudak, 2015; Şen, 2016; Güngör, 2019). When considered as a negative emotional reaction, hormones that cause physical and mental changes begin to be secreted in the human body (Ergin et al., 2016; Gözler et al., 2017; Gökmen \& Ekici, 2018). This leads the individual to either run away or fight or be careful. The human mind begins to focus, and when it thinks that the stress or danger has passed, the body returns to its former state (Kennerley, 2017). Minimizing anxiety by controlling such negative emotions will increase the quality of life in people. Even though anxiety is defined as a negative emotion, keeping this emotion, which is a part of life, under control enables the difficulties encountered (Singh, 2011; Gökmen \& Ekici, 2018). However, the individual's perception of danger and abnormal anxiety without any threat is an unhealthy neurotic anxiety. Such anxieties are psychological problems and reduce the quality of life by negatively affecting the decision-making mechanism of the individual (Gerçek, 2018).

The first step to minimize anxiety is to determine the factors that create anxiety in the individual. According to research in Turkey, not knowing what to do when graduates and inability to find a suitable job are the anxieties concerned by university students (Uludağ et al., 2014; Karabudak, 2015; Bilgici, 2016; Erdas et. al, 2017; Uçak \& Bindak, 2017; Güngör, 2019; Kuşcal1, 2019; Şenses, 2019). Profession is the name of the title gained at the end of an intense education and work process in order to be able to take place in the society and meet the material and spiritual needs of life (Uludağ et al., 2014; Şen, 2016). Some professions tire the mind because they require constant mental activities, while some professions tire the body. In working conditions, the individual is faced with many stimulants. While such stimulants provide the individual to be attentive positively, they can also include negativities such as anxiety, hopelessness and burnout. Job anxiety may also change according to the working conditions of each profession. For example, while a construction workers' anxiety is work safety, a businessman's anxiety is a profit-loss relationship (Uludağ et al., 2014; Çelik, 2017).

Most of the studies on the concept of job anxiety and related variables in the literature have been conducted for teachers who are educated in different fields (Özdayı, 2000; Bozdam, 2008; Saracaloğlu et al., 2009; Kafkas et al., 2010; Çubukçu \& Dönmez, 2011; Yıldırım, 2011; Dursun \& Karagün, 2012; Cabı \& Yalçınalp, 2013; Türkdoğan, 2014; Varol et al., 2014; Bilgici, 2016; Şen, 2016; Uygun et al., 2016; Çelik, 2017; Deniz \& Tican, 2017; Erdas et al., 2017; Gözler et al., 2017; Uçak \& Bindak, 2017; Balaman \& Gelibolu, 2018; Gökmen \& Ekici, 2018; Gerçek, 
2018; Ünlü \& Erbaş, 2018; Uluyol \& Şahin, 2018; Güngör, 2019; Güngör \& Gül, 2019; Kahraman \& Çelik, 2019; Sarıtaş, 2019; Şahin, 2019; Kara, 2020).

Yavuz (2016) also concluded that the freshman students of the Faculty of Education have a moderate level of student attitudes towards the advantages of distance education, and a slightly higher attitude towards disadvantages. Ülkü (2018) states in her Master's thesis that teachers who work in primary schools have a moderate attitude towards distance education and are mostly negative. Yilmaz (2020) thinks that distance education is a disadvantage compared to face-to-face education and when the total answers obtained from students are considered, most of the students think that all courses will be inadequate with distance education, even if they are theory and practice. In Yalman's (2013) study, it was stated that $76.57 \%$ of the pre-service teachers participating in the study would still choose formal education even if the program they studied was a distance education alternative. Karakuş et al. (2020) investigated the views on the distance education process offered to Turkish teacher candidates during the pandemic period. As a result, $62 \%$ of the teacher candidates participating in the study stated that they preferred face-to-face education, $33.7 \%$ of them stated that distance and face-to-face education could be used together, and only 4 of them wanted to continue the lessons with distance education in the future.

Akçay and Gökçearslan (2016) used Adobe Connect real-time virtual classroom tool in their studies to determine the student perceptions of distance education method in their graphic design program at Gazi University, and the students found the distance education method useful and easy to use. Seven (2012), in his study comparing the success levels of students attending distance and formal education in English, concluded that students who continue distance education are more successful than students who continue formal education. Yenilmez, et al. (2017) found that teacher candidates' attitudes towards distance education were generally above average.

Studies have shown that; students' skill levels and attitudes affect their perspectives on the online learning environment (Drennan et al., 2005). Researchers state that students need to have self-efficacy in various fields in order to be successful in distance education (Becer, 2005; Çakın \& Akyavuz, 2020). Students who are educated in graphic design departments and who can use the technological infrastructure at a certain level participated in the study. This study is important in terms of determining the level of job anxiety faced by graphic designer candidates during their education, taking necessary precautions, supporting them in eliminating these concerns, raising their awareness on the subject and making determinations to reduce job anxiety. It is important to know the thoughts of students towards distance education especially during the pandemic period in order to increase the quality of education. For this purpose, the following research questions were sought.

1) What are the perspectives of graphic design students about distance education?

2) Is there a difference in the perspectives of students towards distance education according to their gender, grades, parent's education, level of satisfaction and the reason for choosing the program?

3) Is there a difference in the perspectives of students towards factors of distance education according to their gender, grades, parent's education, level of satisfaction and the reason for choosing the program?

4) What is the job anxiety level of graphic design students?

5) Is there a difference in job anxiety levels of students according to their gender, grades, parent's education, level of satisfaction and the reason for choosing the program?

6) Is there a difference in the factors of job anxiety levels according to their gender, grades, parent's education, level of satisfaction and the reason for choosing the program?

7) Is there a significant relationship between students' attitudes towards distance education and the job anxiety levels?

8) Is there a significant relationship between factors of distance education attitude and job anxiety levels?

The answers sought were collected on a voluntary basis via Google Forms through a survey. SPSS 21 (Statistical Package for the Social Sciences) program was used in the analysis of the data. Within the scope of the study, the professional concerns and problems experienced by the students studying in the Graphic Design Department during the pandemic (covid-19) period were studied.

\section{Method}

In this research; during the pandemic period, a descriptive survey model was used to determine the perspectives and job anxiety of the students of the Graphic Design Department towards distance education. The descriptive survey model is used for studies in which participants' thoughts, interests, skills and attitudes are investigated on a specific topic or event (Büyüköztürk et al., 2011). 
The sample of the research consists of students studying in the field of graphic design in the 2020-2021 academic year in Turkey. The stratified sampling method was used in sample selection. The sampling was carried out with the voluntary participation of 358 students from İnönü University, Beykent University, Mustafa Kemal University, Sıtkı Koçman University, Aksaray University, 18 Mart University, Karatekin University and Karatay University. Research data were collected from Google Forms through a questionnaire created by the researchers

Personal Information Form developed by the researcher was used as the data collection tool in the study. In order to determine students' thoughts about the distance education and job anxieties, "Attitude Scale towards Distance Education" developed by Ağır et al. (2008) and "Job Anxiety Scale for Teacher Candidates" by Cabı and Yalçınalp (2013) were used. The scales used in the study are scales whose validity and reliability analyzes have been made before.

\section{Personal Information Form:}

The Personal Information Form was created by the researcher in order to reach personal information about the sample group of the study. This form consists of a question about the students of the Graphic Design (GD) Department about their gender, grade, parent's education, the reason for choosing the program, satisfaction level from the program, family income, where the family lives, and whether there is internet at home.

Distance Education Attitude Scale (DEAS):

The scale, developed by Ağır et al. (2008), consists of 21 items. 14 of the items have positive and 7 negative statements. The scale has a five-point Likert type factor structure and scores specify the participants' level of agreement to a statement typically in five points: (1) Strongly disagree; (2) Disagree; (3) Neither agree nor disagree; (4) Agree; (5) Strongly agree. If the score obtained from the scale is close to 5, it means satisfaction of distance education, and if it is close to 1 , it means dissatisfaction. The Kaiser-Meyer-Olkin (KMO) coefficient of the scale was 0.814 , the Bartlett Test significance value was 0.000 , and the Cronbach-alpha reliability coefficient was 0.835 . In this study, Cronbach's alpha value for the distance education attitude scale was found to be 0.933 . This shows that the reliability level of the scale is high.

Job Anxiety Scale (JAS):

Developed by Cabı and Yalçınalp (2013), the scale consists of 45 items. First, the scale was applied to prospective teachers. Therefore, some statements were excluded due to the study group. 31 statements were used to reflect the job anxiety of the students. A 5-point scale was used to determine the anxiety level of students' future plans. If the score is close to 5 , it is stated that job anxiety is high, if it is close to 1 , it is low. Cronbach's alpha coefficients vary between 0.94 and 0.67 in the literature. In this study, Cronbach's alpha value for the job anxiety scale was found to be 0.956 . This value shows that the reliability level of the scale is high.

SPSS 21 (Statistical Package for the Social Sciences) statistical software was used for data analysis. Hypothesis tests were used to measure the differences between groups by giving descriptive statistics for the frequency tables of the data. In addition, correlation analysis was applied for between scales. Analysis results are included in the findings section.

\section{Results and Findings}

Before passing on to the analyses regarding the questions for which answers were sought in the study, the information about the basic variables of the participants was included. The total number of students participating in the study is 358,237 of them are female students $(66.2 \%)$ and $121(33.8 \%)$ are male students. 76 students $(21.2 \%)$ were in the first grade (freshman), 93 students $(26.0 \%)$ were in the second grade (Sophomore), 83 students $(23.2 \%)$ were in the third grade (Junior), and $106(29.6 \%)$ were in the fourth grade (Senior). According to the maternal education level of the participants; the mothers of $13(3.6 \%)$ were illiterate, $132(36.9 \%)$ were primary school graduates, 83(23.2\%) secondary school, 84(23.5\%) high school, $46(12.8 \%)$ graduated from an undergraduate program. When the father's education level of the students was examined, $102(28.5 \%)$ were primary school, 73 (20.4\%) were secondary school 111 (31.0\%) were high school graduates, and $72(20.1 \%)$ were undergraduate or completed his master's education. Results are summarized in Table 1. 
Table 1. Demographic statistics of participants

\begin{tabular}{|c|c|c|c|c|c|c|c|}
\hline & Variables & Frequency & Percentage & & Variables & Frequency & Percentage \\
\hline \multirow{2}{*}{ Gender } & Female & 237 & 66.2 & \multirow{4}{*}{ Grade } & Freshmen & 76 & 21.2 \\
\hline & Male & 121 & 33.8 & & Sophomore & 93 & 26.0 \\
\hline \multirow{5}{*}{$\begin{array}{c}\text { Mother's } \\
\text { Education } \\
\text { Level }\end{array}$} & Illiterate & 13 & 3.6 & & Junior & 83 & 23.2 \\
\hline & Primary school & 132 & 36.9 & & Senior & 106 & 29.6 \\
\hline & Secondary school & 83 & 23.2 & \multirow{5}{*}{$\begin{array}{l}\text { Reasons } \\
\text { for } \\
\text { choosing } \\
\text { the } \\
\text { Program }\end{array}$} & Dream Job & 101 & 28.2 \\
\hline & High School & 84 & 23.5 & & Family Referral & 66 & 18.4 \\
\hline & Undergraduate & 46 & 12.8 & & Counselor Guidance & 45 & 12.6 \\
\hline \multirow{5}{*}{$\begin{array}{c}\text { Father's } \\
\text { Education } \\
\text { Level }\end{array}$} & Illiterate & 0 & 0.0 & & Haphazard Choice & 74 & 20.7 \\
\hline & Primary school & 102 & 28.5 & & Capability \& Future & 72 & 20.1 \\
\hline & Secondary school & 73 & 20.4 & \multirow{3}{*}{$\begin{array}{c}\text { Where the } \\
\text { family } \\
\text { lives }\end{array}$} & City & 276 & 77.1 \\
\hline & High School & 111 & 31.0 & & County & 65 & 18.2 \\
\hline & Undergraduate & 72 & 20.1 & & Village & 17 & 4.7 \\
\hline \multirow{6}{*}{$\begin{array}{c}\text { Satisfaction } \\
\text { Level from } \\
\text { the } \\
\text { Program }\end{array}$} & Very dissatisfied & 22 & 6.1 & \multirow{4}{*}{$\begin{array}{l}\text { Family's } \\
\text { Monthly } \\
\text { Income }\end{array}$} & Less than $300 \$$ & 9 & 2.5 \\
\hline & Dissatisfied & 61 & 17.0 & & $301-450 \$$ & 10 & 2.8 \\
\hline & Neutral & 124 & 34.6 & & $451-600 \$$ & 38 & 10.6 \\
\hline & Satisfied & 104 & 29.1 & & More than $600 \$$ & 301 & 84.1 \\
\hline & Very satisfied & 47 & 13.1 & \multirow{2}{*}{$\begin{array}{c}\text { Internet } \\
\text { access }\end{array}$} & Yes & 313 & 87.4 \\
\hline & & & & & No & 45 & 12.6 \\
\hline
\end{tabular}

The monthly income of the families' frequencies like that 9 families (2.5\%) between 0-300 USD, 10 families (2.8\%) between 301-450 USD, 38 families (10.65\%) between 451- 600 USD, 301 families (84.1\%) 600 USD and over monthly has income (In the period of the survey, 1 US Dollar $=7$ Turkish Liras). The reasons for choosing the Graphic Design department of the participants were examined, 101 (28.2\%) of the students preferred because of their dream job, $66(18.4 \%)$ were guided by the family, $45(12.6 \%)$ were guided by the counselor, 74 students $(20.7 \%)$ stated that they chose the program haphazardly and $72(20.1 \%)$ stated that they have capabilities about the program and the program is going to be a valuable level in the future. Of the students participating in the study voluntarily, $276(77.1 \%)$ reside in a city, $65(18.2 \%)$ in a county and $17(4.7 \%)$ in a village. While 313 of these students $(87.4 \%)$ have internet at their homes, $45(12.6 \%)$ students do not have internet access at their homes. When the satisfaction levels of the students with the program were examined, $22(6.1 \%)$ students were very dissatisfied, 61 (17\%) students were dissatisfied, 124 (34.6\%) students were neutral, 104 (29.1\%) students were satisfied, and 47 (13.1\%) students were very satisfied.

For the analyses to be made within the scope of the study, the normality assumption is primarily considered. However, it is not possible for the scale scores to provide normality assumption as a result of using Likert type scale. Some studies have been suggested that if the kurtosis and skewness values of these scores are within certain intervals, the data provides the assumption of normality (Hair et al., 2013; Tabachnick \& Fidell, 2013). Mean, kurtosis, and skewness values of the mean scores obtained from the statements in this study are as shown in Table 2 (Standard errors are in paranthesis). As it is mentioned in the aforementioned sources, parametric tests will be used in the analyses to be made since the values obtained are between +1 and -1 . The results of the analyses were evaluated at a 95 percent confidence interval unless otherwise stated.

Table 2. Kurtosis and skewness of job anxiety score and distance education attitude score

\begin{tabular}{cccc}
\hline Scales & Mean & Skewness & Kurtosis \\
\hline Job Anxiety & $3.6651(0.04595)$ & $-0.665(0.129)$ & $-0.004(0.257)$ \\
\hline Distance Education Attitude & $2.7155(0.04896)$ & $0.333(0.129)$ & $-0.393(0.257)$ \\
\hline
\end{tabular}

In the analysis results, the job anxiety score was 3.67 and the distance education score was 2.72 . Since the anxiety score and the distance education attitude score ranges are between 1 and 5 , the score obtained indicates that the anxiety levels of the students are above average and the distance education score below the average.

Independent samples t-test was applied to determine whether job anxiety and distance education differed according to gender. Test results and scores obtained by gender are included in Table 3. The t-test results obtained for both scores were interpreted after Levene's test results. Accordingly, job anxiety and distance education 
attitude did not differ significantly between male and female students. While job anxiety is 3.57 in men, it is 3.71 in women. Although there was no significant difference between men and women, it was observed that the anxiety level of women was higher than men.

Table 3. Results of the scales based on gender

\begin{tabular}{ccccccc}
\hline Scale & Gender & $\mathrm{N}$ & Mean & Std. Deviation & Levene's Test for Equality of Variances & Sig. (2-tailed) \\
\hline \multirow{2}{*}{ Job Anxiety } & Male & 121 & 3.5768 & .97178 & \multirow{2}{*}{ Equal variances not assumed } \\
& Female & 237 & 3.7101 & .81068 & \multirow{2}{*}{ Equal variances assumed } \\
\hline \multirow{2}{*}{ Distance Education Attitude } & Male & 121 & 2.7331 & .97708 & .90138 & .798 \\
& Female & 237 & 2.7065 & .906 \\
\hline
\end{tabular}

In order to determine whether there is a difference in terms of maternal education levels, mergers were made between groups that were not distributed homogeneously. While illiterate and primary school graduates constituted group 1, middle school, high school and university graduates were evaluated as group 2. Similarly, the average and independent samples t-test results of groups 1 and 2 are included in Table 4. As seen in Table 4, while the distance education attitude differs among the groups, there was no difference in job anxiety. The distance education attitude of group 2 (2.85) was more positive than group 1 (2.52).

Table 4. Results of the scales based on maternal education level

\begin{tabular}{cccccc}
\hline Scale & Mother's Edu. Groups & N & Mean & $\begin{array}{c}\text { Std. } \\
\text { Deviation }\end{array}$ & $\begin{array}{c}\text { Levene's Test for Equality of } \\
\text { Variances }\end{array}$ \\
\hline \multirow{2}{*}{ Job Anxiety } & Group 1 & 145 & 3.7501 & .77839 & Sig. \\
& Group 2 & 213 & 3.6071 & .92357 & Equal variances not assumed \\
\hline Distance Education & Group 1 & 145 & 2.5214 & .79341 & Equal variances not assumed \\
Attitude & Group 2 & 213 & 2.8477 & .98702 & .001 \\
\hline
\end{tabular}

When looking at whether the distance education attitude and job anxiety differ according to the grades of the students, heterogeneous groups were combined as in the previous analysis. While freshmen and sophomore students formed group 1 , junior and senior students formed group 2 . The results of the independent sample $t$ test made after the merger are shown in Table 5. Although there was no significant difference between the groups in job anxiety, it was observed that the students of the last two grades (group 2) were more anxious than the students of the first two grades. When looking at the distance education attitude, a statistically significant difference was observed between the groups. The distance education attitudes of the students in group 2 (2.81) were more positive than the other group (2.61).

Table 5. Results of the scales based on grades

\begin{tabular}{|c|c|c|c|c|c|c|}
\hline Scale & Grade & $\mathrm{N}$ & Mean & Std. Deviation & Levene's Test for Equality of Variances & Sig. (2-tailed) \\
\hline \multirow{2}{*}{ Job Anxiety } & Group 1 & 169 & 3.5950 & .87686 & \multirow{2}{*}{ Equal variances not assumed } & \multirow{2}{*}{.149} \\
\hline & Group 2 & 189 & 3.7277 & .86017 & & \\
\hline \multirow{2}{*}{ Distance Education Attitude } & Group 1 & 169 & 2.6118 & .88735 & \multirow{2}{*}{ Equal variances not assumed } & \multirow{2}{*}{.045} \\
\hline & Group 2 & 189 & 2.8082 & .95273 & & \\
\hline
\end{tabular}

In the analyzes so far, independent samples t-test is used due to the number of groups being two, and one-way ANOVA tests will be used since the number of groups is more than two after this point. First of all, the differences between the educational levels of the fathers were controlled. The results of the job anxiety and distance education analysis of the fathers' education status of the students is shown in Table 6. 
Table 6. Results of the scales based on fathers' education level

\begin{tabular}{|c|c|c|c|c|c|c|c|c|c|}
\hline Scale & Groups & $\mathrm{N}$ & Mean & & & Sum of squares & $\mathrm{df}$ & $\mathrm{F}$ & Sig. \\
\hline \multirow{4}{*}{ Job Anxiety } & Primary school & 102 & 3.8033 & \multirow{4}{*}{ 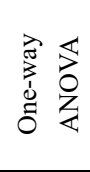 } & Between Groups & 4.655 & 3 & 2.071 & .104 \\
\hline & Secondary school & 73 & 3.4786 & & Within Groups & 265.189 & 354 & & \\
\hline & High School & 111 & 3.6866 & & Total & 269.844 & 357 & & \\
\hline & Undergraduate & 72 & 3.6250 & & & & & & \\
\hline \multirow{4}{*}{ Distance Education Attitude } & Primary school & 102 & 2.5706 & \multirow{4}{*}{ 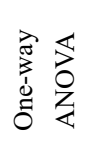 } & Between Groups & 16.187 & 3 & 6.582 & .000 \\
\hline & Secondary school & 73 & 2.5322 & & Within Groups & 290.180 & 354 & & \\
\hline & High School & 111 & 2.7090 & & Total & 306.366 & 357 & & \\
\hline & Undergraduate & 72 & 3.1167 & & & & & & \\
\hline
\end{tabular}

As it can be understood from Table 6, while job anxiety did not differ between father education groups, distance education attitude differed. According to the analyzes made on the basis of homogeneity test results, according to Scheffe and LSD posttests, the distance education attitudes of the students whose father education was undergraduate differed positively from the others.

There are 5 groups as the reasons for choosing the graphic design department. The results of the analysis made to determine whether there is a differentiation between job anxiety and distance education attitudes of these groups are shown in Table 7. In the light of the information obtained from the homogeneity tests, according to the one-way ANOVA test results, there was no differentiation between the program preference groups of both job anxiety and distance education attitudes. On the other hand, if the evaluation is made at a confidence interval of $93 \%$, not $95 \%$, it was observed that those who preferred the program haphazardly felt more anxiety than other groups.

Table 7. Results of the scales based on reasons of choosing the program

\begin{tabular}{|c|c|c|c|c|c|c|c|c|c|}
\hline Scale & Groups & $\mathrm{N}$ & Mean & & & Sum of squares & df & $\mathrm{F}$ & Sig. \\
\hline \multirow{5}{*}{ Job Anxiety } & Counselor Guidance & 45 & 3.6715 & \multirow{5}{*}{ 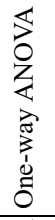 } & \multirow{5}{*}{$\begin{array}{c}\text { Between Groups } \\
\text { Within Groups } \\
\text { Total }\end{array}$} & \multirow{5}{*}{$\begin{array}{c}6.523 \\
263.321 \\
269.844\end{array}$} & \multirow{5}{*}{$\begin{array}{c}4 \\
353 \\
357\end{array}$} & \multirow[t]{5}{*}{2.186} & \multirow[t]{5}{*}{.070} \\
\hline & Haphazard Choice & 74 & 3.8880 & & & & & & \\
\hline & Capability \& Future & 72 & 3.5453 & & & & & & \\
\hline & Family Referral & 66 & 3.5024 & & & & & & \\
\hline & Dream Job & 101 & 3.6905 & & & & & & \\
\hline \multirow{5}{*}{ Distance Education Attitude } & Counselor Guidance & 45 & 2.8100 & \multirow{5}{*}{ 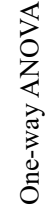 } & \multirow{5}{*}{$\begin{array}{c}\text { Between Groups } \\
\text { Within Groups } \\
\text { Total }\end{array}$} & 1.417 & 4 & \multirow[t]{5}{*}{.410} & \multirow[t]{5}{*}{.801} \\
\hline & Haphazard Choice & 74 & 2.6027 & & & 304.949 & 353 & & \\
\hline & Capability \& Future & 72 & 2.7368 & & & 306.366 & 357 & & \\
\hline & Family Referral & 66 & 2.7348 & & & & & & \\
\hline & Dream Job & 101 & 2.7282 & & & & & & \\
\hline
\end{tabular}

Satisfaction with the program was grouped under three groups, considering the homogeneity criteria. The differentiation between job anxiety and distance education attitudes of those who are satisfied with the program, those who are dissatisfied, and those who are neutral were examined. The results obtained are included in Table 8 . In the light of the information obtained from the variance homogeneity test results of both scales, statistical differentiation between groups was determined. According to the LSD and Scheffe tests, the job anxiety of those who were dissatisfied with the program was higher than the other groups (3.94). Similarly, the distance education attitudes of those who were dissatisfied with the program were found to be lower than the other groups (2.45).

Table 8. Results of the scales based on the satisfaction level of the program

\begin{tabular}{|c|c|c|c|c|c|c|c|c|c|}
\hline Scale & Groups & $\mathrm{N}$ & Mean & & & Sum of squares & df & $\mathrm{F}$ & Sig. \\
\hline \multirow{3}{*}{ Job Anxiety } & Dissatisfied & 83 & 3.9390 & \multirow{3}{*}{ 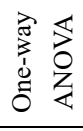 } & Between Groups & 8.158 & 2 & 5.534 & .004 \\
\hline & Neutral & 124 & 3.5973 & & Within Groups & 261.686 & 355 & & \\
\hline & Satisfied & 151 & 3.5701 & & Total & 269.844 & 357 & & \\
\hline \multirow{3}{*}{ Distance Education Attitude } & Dissatisfied & 83 & 2.4518 & \multirow{3}{*}{ 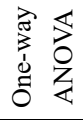 } & Between Groups & 9.014 & 2 & 5.381 & .005 \\
\hline & Neutral & 124 & 2.8766 & & Within Groups & 297.352 & 355 & & \\
\hline & Satisfied & 151 & 2.7281 & & Total & 306.366 & 357 & & \\
\hline
\end{tabular}


Factor analyses:

As a result of the factor analysis applied to the scales, while the job anxiety scale is divided into 4 factors, distance education is divided into 2 factors. After the analyses and Cronbach's alpha reliability tests, the factors of job anxiety were obtained as Economic/Compliance-centered anxiety, Social-centered anxiety, Occupational-centered anxiety and task-centered anxiety. On the other hand, the factors of distance education have also been identified as advantages and limitations. General information of scales and their factors and also reliability analyses of factors as determined by the Cronbach's alfa are as shown in Table 9 .

Table 9. Factors of the scales

\begin{tabular}{ccccc}
\hline Scales & Factors & Number of Statement & Mean & Cronbach's Alpha \\
\hline \multirow{4}{*}{ Job Anxiety } & Economic/Compliance-centered & 8 & 3.8170 & 0.919 \\
& Social-centered & 8 & 3.6705 & 0.871 \\
& Occupational-centered & 6 & 3.2360 & 0.881 \\
& Task-centered & 7 & 3.9449 & 0.866 \\
& Total & 29 & 3.6651 & 0.953 \\
\hline \multirow{3}{*}{ Distance Education Attitude } & Advantages & 13 & 2.8859 & 0.943 \\
& Limitations & 7 & 2.3990 & 0.897 \\
& Total & 20 & 2.7155 & 0.933 \\
\hline
\end{tabular}

Using the 6 demographic characteristics analyzed above for a total of 6 factors, it was examined whether there was any difference between groups. In terms of saving time and page, only the differentiations were mentioned in this paper. When all factors are examined, no differentiation between genders has been detected. When the education level of the mother was examined, in the occupational-centered anxiety factor, group 1 took the value 3.41, while group 2 took the value 3.12. In this case, the job anxiety of students with lower maternal education is higher than the other group. A similar difference was observed in both factors of distance education. The advantages factor was calculated as 2.67 for group 1 and 3.03 for group 2. The limitations factor was calculated as 2.25 for group 1 and 2.50 for group 2 . When grouped grade levels were examined, social-centered anxiety was found to be 3.80 for the last two grades and 3.52 for the first two grades. In terms of distance education limitations, the first two grades were calculated as 2.26 and the last two grades as 2.52 , and statistically significant differences were detected. The results mentioned so far are included in Table 10.

Table 10. Analyses of factors by using Independent Samples T-Test

\begin{tabular}{|c|c|c|c|c|c|c|}
\hline & Sub-dimensions & Groups & $\mathrm{N}$ & Mean & Std. Deviation & Std. Error Mean \\
\hline \multirow{12}{*}{$\begin{array}{l}\dot{\overrightarrow{0}} \\
\overrightarrow{0} \\
\dot{0}\end{array}$} & \multirow{2}{*}{ Social- centered } & Male & 121 & 3.5841 & 1.01688 & .09244 \\
\hline & & Female & 237 & 3.7147 & .91103 & .05918 \\
\hline & \multirow{2}{*}{ Eco/Comp centered } & Male & 121 & 3.7603 & 1.17189 & .10654 \\
\hline & & Female & 237 & 3.8460 & .95829 & .06225 \\
\hline & \multirow{2}{*}{ Occupational-centered } & Male & 121 & 3.1722 & 1.21143 & .11013 \\
\hline & & Female & 237 & 3.2686 & 1.09411 & .07107 \\
\hline & \multirow{2}{*}{ Task- centered } & Male & 121 & 3.8205 & .91520 & .08320 \\
\hline & & Female & 237 & 4.0084 & .89317 & .05802 \\
\hline & \multirow{2}{*}{ Advantage } & Male & 121 & 2.8957 & 1.14155 & .10378 \\
\hline & & Female & 237 & 2.8809 & 1.06386 & .06911 \\
\hline & \multirow{2}{*}{ Limitation } & Male & 121 & 2.4309 & 1.14107 & .10373 \\
\hline & & Female & 237 & 2.3828 & 1.05437 & .06849 \\
\hline \multirow{7}{*}{ 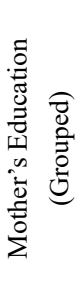 } & \multirow{2}{*}{ Social- centered } & Group 1 & 145 & 3.7366 & .85162 & .07072 \\
\hline & & Group 2 & 213 & 3.6256 & 1.00899 & .06913 \\
\hline & \multirow{2}{*}{ Eco/Comp centered } & Group 1 & 145 & 3.9052 & .89937 & .07469 \\
\hline & & Group 2 & 213 & 3.7570 & 1.11537 & .07642 \\
\hline & \multirow{2}{*}{ Occupational-centered } & Group 1 & 145 & 3.4057 & 1.03653 & .08608 \\
\hline & & Group 2 & 213 & 3.1205 & 1.18487 & .08119 \\
\hline & Task- centered & Group 1 & 145 & 3.9941 & .78425 & .06513 \\
\hline
\end{tabular}




\begin{tabular}{|c|c|c|c|c|c|c|}
\hline & & Group 2 & 213 & 3.9115 & .97722 & .06696 \\
\hline & \multirow{2}{*}{ Advantage } & Group 1 & 145 & 2.6695 & 1.00370 & .08335 \\
\hline & & Group 2 & 213 & 3.0332 & 1.12229 & .07690 \\
\hline & \multirow{2}{*}{ Limitation } & Group 1 & 145 & 2.2463 & .98824 & .08207 \\
\hline & & Group 2 & 213 & 2.5030 & 1.13369 & .07768 \\
\hline \multirow{12}{*}{ 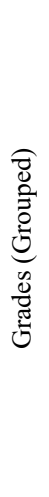 } & \multirow{2}{*}{ Social- centered } & Group 1 & 169 & 3.5222 & .97096 & .07469 \\
\hline & & Group 2 & 189 & 3.8032 & .91062 & .06624 \\
\hline & \multirow{2}{*}{ Eco/Comp centered } & Group 1 & 169 & 3.8055 & .99055 & .07620 \\
\hline & & Group 2 & 189 & 3.8274 & 1.07493 & .07819 \\
\hline & \multirow{2}{*}{ Occupational-centered } & Group 1 & 169 & 3.1627 & 1.13228 & .08710 \\
\hline & & Group 2 & 189 & 3.3016 & 1.13516 & .08257 \\
\hline & \multirow{2}{*}{ Task- centered } & Group 1 & 169 & 3.8876 & .94724 & .07286 \\
\hline & & Group 2 & 189 & 3.9962 & .86237 & .06273 \\
\hline & \multirow{2}{*}{ Advantage } & Group 1 & 169 & 2.8020 & 1.03031 & .07925 \\
\hline & & Group 2 & 189 & 2.9609 & 1.13669 & .08268 \\
\hline & \multirow{2}{*}{ Limitation } & Group 1 & 169 & 2.2587 & 1.01459 & .07805 \\
\hline & & Group 2 & 189 & 2.5246 & 1.12879 & .08211 \\
\hline
\end{tabular}

In the analysis performed by using factors according to father's education levels, no difference was found in terms of job anxiety factors as shown in Table 11. In terms of distance education advantages and limitations factors, it was observed that the education level of the fathers differed significantly from other education levels. The scores obtained in both factors (3.31 for Advantage and 2.75 for Limitation) were higher than the scores of other levels (according to LSD test result).

Table 11. Analyses of factors based on fathers' education level

\begin{tabular}{cccccc}
\hline Sub-dimensions & Groups & $\mathrm{N}$ & Mean & Std. Deviation & Std. Error \\
\hline \multirow{5}{*}{ Eco/Comp centered } & Primary school & 102 & 3.9081 & .97587 & .09663 \\
& Secondary school & 73 & 3.6764 & 1.03158 & .12074 \\
& High School & 111 & 3.8255 & 1.07202 & .10175 \\
& Undergraduate & 72 & 3.8177 & 1.06541 & .12556 \\
\hline \multirow{5}{*}{ Social-centered } & Primary school & 102 & 3.8603 & .87620 & .08676 \\
& Secondary school & 73 & 3.5616 & .86027 & .10069 \\
& High School & 111 & 3.6829 & 1.02923 & .09769 \\
& Undergraduate & 72 & 3.4931 & .97253 & .11461 \\
\hline \multirow{5}{*}{ Occupational-centered } & Primary school & 102 & 3.4739 & 1.09949 & .10887 \\
& Secondary school & 73 & 2.9064 & 1.13515 & .13286 \\
& High School & 111 & 3.2583 & 1.14255 & .10845 \\
& Undergraduate & 72 & 3.1991 & 1.10718 & .13048 \\
\hline \multirow{5}{*}{ Task-centered } & Primary school & 102 & 4.0140 & .87152 & .08629 \\
& Secondary school & 73 & 3.7162 & 1.00607 & .11775 \\
& High School & 111 & 4.0051 & .90800 & .08618 \\
& Undergraduate & 72 & 3.9861 & .80925 & .09537 \\
\hline \multirow{5}{*}{ Limitation } & Primary school & 102 & 2.7602 & 1.07678 & .10662 \\
& Secondary school & 73 & 2.6691 & 1.16050 & .13583 \\
& High School & 111 & 2.8669 & 1.02271 & .09707 \\
& High School & 111 & 2.4157 & 1.04705 & .09938 \\
& Undergraduate & 72 & 2.7520 & 1.16724 & .13756 \\
\hline & Primary school & 102 & 2.2185 & .97942 & .09698 \\
& Secondary school & 73 & 2.2779 & 1.12533 & .13171 \\
& & & & &
\end{tabular}

On the other hand, when the reasons for choosing the program were examined in Table 12 shows that the anxiety of those who made haphazard choices in the occupational-centered anxiety factor differed according to other reasons 
(3.59, based on the LSD test result). Among the reasons for preference, no differentiation was found in terms of distance education factors.

Table 12. Analyses of factors based on the reasons choosing the program

\begin{tabular}{|c|c|c|c|c|c|}
\hline Sub-dimensions & Groups & $\mathrm{N}$ & Mean & Std. Deviation & Std. Error \\
\hline \multirow{5}{*}{ Eco/Comp centered } & Counselor Guidance & 45 & 3.7389 & 1.04678 & .15605 \\
\hline & Haphazard Choice & 74 & 4.0355 & .86690 & .10077 \\
\hline & Capability \& Future & 72 & 3.7413 & 1.07842 & .12709 \\
\hline & Family Referral & 66 & 3.5758 & 1.17626 & .14479 \\
\hline & Dream Job & 101 & 3.9035 & .98851 & .09836 \\
\hline \multirow{5}{*}{ Social-centered } & Counselor Guidance & 45 & 3.8067 & .87710 & .13075 \\
\hline & Haphazard Choice & 74 & 3.8919 & .90526 & .10523 \\
\hline & Capability \& Future & 72 & 3.5590 & 1.03716 & .12223 \\
\hline & Family Referral & 66 & 3.5758 & .99949 & .12303 \\
\hline & Dream Job & 101 & 3.5891 & .89291 & .08885 \\
\hline \multirow{5}{*}{ Occupational-centered } & Counselor Guidance & 45 & 3.2556 & 1.03998 & .15503 \\
\hline & Haphazard Choice & 74 & 3.5901 & 1.05848 & .12305 \\
\hline & Capability \& Future & 72 & 3.0949 & 1.14135 & .13451 \\
\hline & Family Referral & 66 & 3.0354 & 1.20487 & .14831 \\
\hline & Dream Job & 101 & 3.1997 & 1.13847 & .11328 \\
\hline \multirow{5}{*}{ Task-centered } & Counselor Guidance & 45 & 3.9683 & .77883 & .11610 \\
\hline & Haphazard Choice & 74 & 4.0753 & .82869 & .09633 \\
\hline & Capability \& Future & 72 & 3.7897 & .85914 & .10125 \\
\hline & Family Referral & 66 & 3.8377 & 1.10284 & .13575 \\
\hline & Dream Job & 101 & 4.0198 & .88871 & .08843 \\
\hline \multirow{5}{*}{ Advantage } & Counselor Guidance & 45 & 2.9385 & 1.12596 & .16785 \\
\hline & Haphazard Choice & 74 & 2.8067 & 1.00668 & .11702 \\
\hline & Capability \& Future & 72 & 2.8472 & 1.04969 & .12371 \\
\hline & Family Referral & 66 & 2.8566 & 1.27522 & .15697 \\
\hline & Dream Job & 101 & 2.9673 & 1.04107 & .10359 \\
\hline \multirow{5}{*}{ Limitation } & Counselor Guidance & 45 & 2.5714 & 1.21715 & .18144 \\
\hline & Haphazard Choice & 74 & 2.2239 & .94290 & .10961 \\
\hline & Capability \& Future & 72 & 2.5317 & 1.03133 & .12154 \\
\hline & Family Referral & 66 & 2.5087 & 1.19026 & .14651 \\
\hline & Dream Job & 101 & 2.2843 & 1.06818 & .10629 \\
\hline
\end{tabular}

When the satisfaction levels of the program are examined, the scores of the students who were dissatisfied with the program differed from those who were neutral and satisfied in all factors as seen in Table 13. The economic/compliance-centered anxiety score was calculated as 4.07 , social-centered anxiety 3.88 , occupational-centered anxiety 3.66, and task-centered anxiety 4.19. It was determined that those who were not satisfied with the program in all factors of job anxiety were more anxious than others. The distance education advantages score was calculated as 2.64 and the distance education limitations score was calculated as 2.10 , and it was statistically different from the others and was low.

Table 13. Analyses of factors based on satisfaction level of the program

\begin{tabular}{llllll}
\hline Sub-dimensions & Groups & $\mathrm{N}$ & Mean & Std. Deviation & Std. Error \\
\hline \multirow{4}{*}{ Eco/Comp centered } & Dissatisfied & 83 & 4.0723 & .92272 & .10128 \\
& Neutral & 124 & 3.7601 & 1.08489 & .09743 \\
& Satisfied & 151 & 3.7235 & 1.03407 & .08415 \\
\hline \multirow{3}{*}{ Social-centered } & Dissatisfied & 83 & 3.8780 & .92311 & .10132 \\
& Neutral & 124 & 3.6401 & 1.00704 & .09043 \\
& Satisfied & 151 & 3.5815 & .90122 & .07334 \\
\hline
\end{tabular}




\begin{tabular}{llllll}
\hline \multirow{4}{*}{ Occupational-centered } & Dissatisfied & 83 & 3.6647 & .94586 & .10382 \\
& Neutral & 124 & 3.1237 & 1.19126 & .10698 \\
& Satisfied & 151 & 3.0927 & 1.13000 & .09196 \\
\hline \multirow{3}{*}{ Task-centered } & Dissatisfied & 83 & 4.1928 & .76686 & .08417 \\
& Neutral & 124 & 3.8698 & .91501 & .08217 \\
& Satisfied & 151 & 3.8704 & .94435 & .07685 \\
\hline \multirow{3}{*}{ Advantage } & Dissatisfied & 83 & 2.6432 & 1.07689 & .11820 \\
& Neutral & 124 & 3.0323 & 1.10593 & .09932 \\
& Satisfied & 151 & 2.8991 & 1.06581 & .08673 \\
\hline \multirow{3}{*}{ Limitation } & Dissatisfied & 83 & 2.0964 & .97788 & .10734 \\
& Neutral & 124 & 2.5876 & 1.13297 & .10174 \\
& Satisfied & 151 & 2.4106 & 1.06603 & .08675 \\
\hline
\end{tabular}

Considering the correlation between the two scales, a score of -0.058 was obtained. Although this is not statistically significant, it is also the determination that there is no relationship between these two scales. When looking at the relationship between the scales and their own factors, it was observed that the job anxiety scale had a correlation coefficient of 0.905 with economic/compliance-centered anxiety, 0.801 with social-centered anxiety, 0.859 with occupational-centered anxiety, and 0.863 with task-centered anxiety. Therefore, all factors were identified in a positive and strong relationship with the scale. Similarly, a correlation coefficient of 0.927 was calculated between the distance education scale and the advantages factor, and 0.713 with the limitations factor. A positive and strong relationship was found between the scale and the factors. Considering the factors between the scales, it was seen that the distance education limitations factor was in a significant relationship with all the factors of the job anxiety scale. Although the relationship is weak, it has been found to be negative. As the distance education limitations of students' increase, it is expected that their economic/compliance-centered, social-centered, occupational-centered, and task-centered anxieties will decrease, albeit weakly. The correlation matrix showing the relationship between scales and factors is shown in Table 14.

Table 14. Correlations of the factors and the scales

\begin{tabular}{|c|c|c|c|c|c|c|c|c|c|}
\hline Correlatio & & 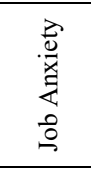 & 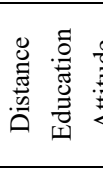 & 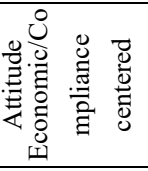 & 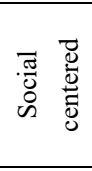 & 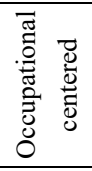 & 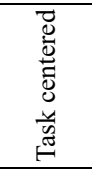 & 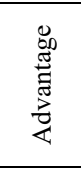 & . \\
\hline \multirow{2}{*}{ Job Anxiety } & Pearson C. & 1 & -.058 & $.905^{*}$ & $.801 *$ & $.859^{*}$ & $.863 *$ & .050 & $-.235^{*}$ \\
\hline & Sig. (2-tailed) & & .274 & .000 & .000 & .000 & .000 & .343 & .000 \\
\hline \multirow{2}{*}{ Distance Ed. Attitude } & Pearson C. & -.058 & 1 & $-.105^{*}$ & -.029 & -.035 & -.032 & $.927^{*}$ & $.713^{*}$ \\
\hline & Sig. (2-tailed) & .274 & & .046 & .581 & .505 & .540 & .000 & .000 \\
\hline \multirow{2}{*}{ Eco/Comp centered } & Pearson C. & $.905^{*}$ & $-.105 *$ & 1 & $.623 *$ & $.716^{*}$ & $.717 *$ & -.004 & $-.250^{*}$ \\
\hline & Sig. (2-tailed) & .000 & .046 & & .000 & .000 & .000 & .940 & .000 \\
\hline \multirow{2}{*}{ Social- centered } & Pearson C. & $.801^{*}$ & -.029 & $.623^{*}$ & 1 & $.536^{*}$ & $.608^{*}$ & .067 & $-.197 *$ \\
\hline & Sig. (2-tailed) & .000 & .581 & .000 & & .000 & .000 & .206 & .000 \\
\hline \multirow{2}{*}{ Occupational-centered } & Pearson C. & $.859 *$ & -.035 & $.716^{*}$ & $.536^{*}$ & 1 & $.710^{*}$ & .050 & $-.180^{*}$ \\
\hline & Sig. (2-tailed) & .000 & .505 & .000 & .000 & & .000 & .346 & .001 \\
\hline \multirow{2}{*}{ Task-centered } & Pearson C. & $.863^{*}$ & -.032 & $.717^{*}$ & $.608^{*}$ & $.710^{*}$ & 1 & .053 & $-.178^{*}$ \\
\hline & Sig. (2-tailed) & .000 & .540 & .000 & .000 & .000 & & .320 & .001 \\
\hline \multirow{2}{*}{ Advantage } & Pearson C. & .050 & $.927^{*}$ & -.004 & .067 & .050 & .053 & 1 & $.397^{*}$ \\
\hline & Sig. (2-tailed) & .343 & .000 & .940 & .206 & .346 & .320 & & .000 \\
\hline \multirow{2}{*}{ Limitation } & Pearson C. & $-.235^{*}$ & $.713^{*}$ & $-.250^{*}$ & $-.197 *$ & $-.180 *$ & $-.178 *$ & $.397 *$ & 1 \\
\hline & Sig. (2-tailed) & .000 & .000 & .000 & .000 & .001 & .001 & .000 & \\
\hline
\end{tabular}

Note. $*$ shows that statistically significant at $95 \%$ confidence level.

\section{Discussion}

The education systems of all countries that went through a difficult period during the pandemic period were adversely affected by this epidemic. In order to slow down the epidemic, all education and training activities have 
started to be provided by distance education instead of face-to-face education with the support of the states. Although theoretical courses and computer-based applied courses were given in the distance education model before, difficulties were experienced due to the first time the courses conducted in the workshop/laboratory were given online. The studies carried out in this difficult period are generally aimed at informing about the problems in distance education and how the programs to be applied in distance education and how the pandemic will affect the future education system (Hill et al., 2020; Moorhouse, 2020; Moyo, 2020; Nuland et al., 2020; Quezada, Talbot, \& Quezada-Parker, 2020). Since there are almost no comparable studies in the field of graphic design, the studies published before the epidemic period is compared with the results obtained in this study. The absence of the Graphic Design Department at much of universities in Turkey has led to the small number of students that make up the universe. In addition, the fact that the students who do not have internet access were excluded from the scope of the study because the data were collected online is one of the limitations of the study. This limitation was taken into account when interpreting the findings in the study. In this research, during the Covid-19 pandemic period, the distance education attitudes and the job anxiety levels of the students studying in the Graphic Design Department, where applied workshop courses are concentrated, were examined.

When the average scores of the Job Anxiety Level and Distance Education attitude scales are examined, the job anxiety of the students is above the average and the distance education attitude is below the average. It was predicted that the students of the Graphic Design Department were positive to the distance education due to their proficiency in technology and their use of educational programs. However, the results were below the average level. When the literature was searched, it was concluded that the participants preferred face-to-face education, especially in the studies conducted during the pandemic period (Yalman, 2013; Genç \& Gümrükçüoğlu, 2020; Karakuş et al., 2020; Karatepe, Küçükgençay, \& Peker ,2020; Kürtüncü \& Kurt, 2020; Sakarya \& Zahal, 2020; Serçemeli \& Kurnaz, 2020; Mladenova, Kalmukov, \& Valova, 2020; Turan \& Gürol 2020; Yılmaz, 2020). However, there are studies that participants find distance education useful and easy to use (Seven, 2012; Akçay \& Gökçearslan, 2016; Yenilmez, Balbağ, \& Turgut, 2017; Afşar \& Büyükdoğan, 2020; Başaran et al., 2020; Buluk \& Eşitti, 2020; Coolican, Borras, \& Strong, 2020; Osman, 2020). Yavuz (2016), on the other hand, concluded that student attitudes towards the advantages of distance education are at a medium level as a result of the study applied to the first-grade students of the Faculty of Education. Ülkü (2018) concluded that teachers working in primary schools have a moderate attitude towards distance education.

According to the findings of the research, although the relationship between the gender variable and the distance education attitude does not indicate a statistically significant difference, male students have higher scores than female students. In other words, it is seen that their satisfaction with distance education is higher. Since the use of technological tools, especially computers, in distance education, male students are more curious and prone to technology with the responsibility required by the gender role imposed by the society. In the literature, there are studies that do not find a significant difference between gender and the attitude towards distance education and have reached similar findings with this study (Ağır, Gür, \& Okçu, 2008; Yalman, 2013; Barış, 2015; Yavuz, 2016; Ülkü, 2018; Karadağ \& Yücel, 2020; Y1lmaz, 2020). However, there are also studies in the literature that indicate that the attitude of students towards distance education vary according to gender (Fidan, 2016; Yenilmez, Balbağ, \& Turgut, 2017; Aktaş et al., 2020; Buluk \& Eşitti, 2020). When the relationship between gender variable and job anxiety is examined in the study, the job anxiety of female students is higher than that of male. However, this difference was not statistically significant. The reasons why female students feel more job anxiety compared to male students may be due to the fact that women can express and show their feelings more easily in the face of stress. At the same time, it can be counted that women play an equal role with men in business life and become role models. It can also be thought that the growth of both groups in similar social-cultural environments and the changing understanding of families today and having similar educational opportunities without discriminating between girls and boys may be effective. In addition, the change in the idea that only men should work in the past may be effective in women taking an equal role in business life with men. Factors such as the structure of the universities and the attitude of the university lecturers towards students without discriminating between female and male students may cause this difference to not occur. Considering the studies investigating the job anxiety levels of university students according to the gender variable, the results of the study examining the job anxiety levels of the pre-service teachers who attend Physical Education (Ünlü \& Erbaş, 2018; Kafkas et al., 2010) and various departments (Özdayı, 2000; Bozdam, 2008; Saracaloğlu, Kumral, \& Kanmaz, 2009; Yıldırım, 2011; Karabudak, 2015; Bozgün \& Kösterelioğlu, 2018; Güngör \& Gül, 2019; Kahraman \& Çelik, 2019; Sarıtaş, 2019) and the undergraduate students who receive Physiotherapy and Rehabilitation (Özdinç et al., 2018) according to the gender variable support the findings obtained in this study. However, studies with different findings were reached in the literature review (Singh, 2011; Varol, Erbaş, \& Ünlü, 2014; Ergin, Uzun, \& Topaloğlu, 2016; Uygun, Avaroğulları, \& Oran, 2016; Çelik, 2017; Deniz \& Tican, 2017; Erdas, Asıkuzun, \& Recepoğlu, 2017; Gözler, 
Bozgeyikli, \& Avc1, 2017; Uçak \& Bindak, 2017; Çınar, 2018; Uluyol \& Şahin, 2018; Güngör, 2019; Kuşcall, 2019; Şahin, 2019; Şenses, 2019; Kara, 2020). Finally, there is no statistically significant relationship between gender and the factors of the distance education and the job anxiety.

It has been stated in many studies that the responsibilities of parents or other individuals sharing the same environment in distance education, especially during the pandemic (covid-19) period, have increased even more than before the pandemic. The distance education attitudes of the students whose mother's education level was illiterate and who graduated from primary school were calculated lower than those who graduated from secondary school, high school and undergraduate. According to the findings, students with higher maternal education levels look distance education more positively. The job anxiety levels of students whose mothers are illiterate and primary school graduates are higher than those whose mothers' education level is secondary, high school and undergraduate. However, this result is not statistically significant. The reason why there is no difference is that students who actively use developing technology such as television and the internet can be influenced not only by their parents but also by famous scientists as role models. Şenses (2019) who reached different results, found that the education level of the mother affects the job anxiety of the students. When the factors of job anxiety level and mother's education level were examined, it was found that students whose mothers were illiterate or graduated from primary school experienced occupational-centered anxiety. As the education level of the mother increased, a positive differentiation was found in terms of distance education attitude in both advantage and limitation factors.

The job anxiety levels of those who graduated from primary school were high when consider the education level of fathers of the students. However, this result was not statistically significant. Şenses (2019) concluded in his study that the education level of fathers does not affect students' job anxiety. Another finding is that students with a high education level of fathers have high levels of satisfaction with distance education. Educated parents have different perspectives on life and events. Good financial means are not sufficient for a child's development. Fathers with a high level of education can guide their children about what to do and how. Especially during the pandemic process, they can better adapt their children to distance education. Job Anxiety factors were examined according to the education level of the father. A significant relationship was not found between the fathers' education level and the job anxiety. A positive differentiation was found in terms of distance education attitude in both the advantage and the limitation factors of the students whose fathers are undergraduate degrees. In this period when many difficulties were experienced during the pandemic period, conscious parents are aware of the advantages and limitations of distance education, and it is thought that they help their children to meet their needs and deficiencies.

The satisfaction level of the participants from the distance education was found below the average. The answer of the hypothesis whether the grade level affects this negative thought or not has been examined. In another finding obtained in the study, the relationship between the grade variable and Distance Education attitude was examined and a statistically significant difference was found between the grades. The level of attitude towards distance education is higher in senior and junior students than sophomore and freshmen. The reason for this may be those senior and junior students, who have reached a certain level in education, are not obliged to come to school, so they can spare their time to work outside of school. These results are not in line with the findings of Yilmaz (2020) in his research. Job anxiety levels were examined according to the grade variable. It was determined that the anxiety level of 3rd and 4th grades was higher than the other grades. But there is no statistically significant relationship. There are studies in the literature reaching similar findings (Güngör, 2019; Kuşcalı, 2019; Sarıtaş, 2019; Kara, 2020). As in all professions, it is very natural that 3rd grade, especially 4th grade students, who study in Graphic Design, have high levels of job anxiety. Especially during the pandemic period, the increasing number of graduates, decrease in job opportunities, closing businesses, lack of strong references, low wages, lack of personal or academic skills can cause students to worry before graduating. However, when the literature is examined, there are studies showing that there is a difference in the job anxiety levels of the students according to the grade level. When the factors of Job Anxiety Level and grades were examined, it was seen that junior and senior students experienced more social-centered anxiety than other grades.

One of the questions to be answered is whether the reason for choosing the department has an effect on the student's perspective on distance education and job anxiety. In the study, no statistically significant difference was found between the distance education satisfaction level according to the reason of students choosing Graphic Design Department. A meaningful difference was found in the job anxiety levels according to the students' reason for choosing the Graphic Design Department at 93\% confidence level. The level of anxiety is at the highest level in students who make their choice haphazard. Unknowingness may have caused anxiety in students. Since students naturally trust their families and counselors who guide them, it is natural that students who consciously choose their profession by researching this part of their work areas have a low level of anxiety. Erdas et al. (2017) found that the job anxieties of prospective teachers differed significantly according to whether they chose the teaching 
profession and preschool teaching department willingly or not. In addition, Bilgici (2016) found a significant difference between pre-school education teacher candidates' anxiety scores according to their reasons for choosing the job. Türkdoğan (2014) reached a different conclusion that the professional anxiety levels of prospective teachers did not differ significantly according to the reason for their preference. It was investigated whether there is a meaningful relationship between the students' reason for choosing the Graphic Design Department and the factors of the job anxiety level. Those who chose the department haphazardly differed statistically that they experienced occupational-centered anxiety. Students especially do not want their colleagues to think that their field knowledge is insufficient. On the other hand, there is no statistically significant relationship between factors of distance education and the reasons of choosing the graphic design program.

A statistically significant relationship was found between the level of satisfaction with the program and job anxiety levels of the students participating in the study. The job anxieties of the group with a low level of satisfaction were found to be high. Having an education in a program where people cannot find their expectations negatively affects their personal and professional development. This brings failure and anxiety with it. These students must be identified and interviewed by experts. It should clearly determine what their expectations were from this program they attended and why they were not satisfied. In the light of these, necessary information and guidance should be provided. Since the job anxieties of students who take Graphic Design education are generally high, each university can conduct online guidance work for their own students. There is also a significant relationship between students' program satisfaction levels and their perspective towards distance education. Students with low level of satisfaction with the program view distance education negatively. The group with a positive attitude towards distance education is the students whose level of satisfaction with the program is moderate. A statistically significant relationship was observed between program satisfaction levels and the job anxiety factors. The group with a low level of satisfaction with the program thinks that they will experience anxiety in economic/compliance-centered, social-centered, task-centered, and occupational-centered anxieties. It was observed that the students with low satisfaction level have low scores from the advantages and limitations factors of distance education and had negative attitudes towards distance education.

The correlation between distance education attitude and job anxiety is calculated almost zero. Therefore, it is possible to say that distance education has no effect on job anxiety for graphic design student at pandemic period. In a similar manner, job anxieties don't affect the distance education attitude. When the correlation between the job anxiety scale and its factors was examined, a significant and positive relationship was found. For example, a person experiencing economic or compliance-centered anxiety also experiences task-centered, social-centered and occupational-centered anxiety. This gives the impression that the types of anxiety are fed from the same source. The findings obtained by Kuşcalı (2019) conducted in order to measure the job anxieties of the students of the Faculty of Islamic Sciences are in line with the result of this study. Karabudak (2015), who reached similar results, concluded that each factors of the job anxiety scale had the same and statistically significant effect on the total job anxiety score. There is a positive and significant relationship between the distance education attitude scale and its factors. This result is in line with the results of Yavuz's (2016) study. In the study, it was seen that there was a negative relationship between the limitation factor of the distance education attitude scale and all job anxiety factors. It is seen that the university student who is studying graphic design is aware of the limitations of distance education and can take his own precautions because he can use the possibilities of technology very easily, which positively affects his job anxiety.

Unfortunately, the world is faced to fact that the mutated virus will be effective for a longer period of time. It seems that a long period of time is needed to return to normal lives. In this period when communication and socialization between people are almost non-existent, students have been continuing their education online for about three terms. It is normal for students to experience various psychological anxieties during this process. Graphic Design education should be open to continuous development and innovations and students should adapt to these changes. It is possible to experience concerns arising from not being able to achieve this harmony. At the same time, in order for distance education to be more effective, it is necessary to raise more awareness of the students on this issue and to eliminate the deficiencies by receiving feedback. Research should be done on the strategies to cope with the anxiety experienced by the students in this process. It is important that the IT team inform students and academicians about the operation of the system and provide technical support in case of technical problems in this process. It should not be forgotten that students' psychology, anxiety and stress levels will be reflected in their grades. At the same time, free and unlimited internet service can be offered to all students and parents. Students have both technical (Annur, 2020) and financial problems in accessing the internet (Firmansyah, 2021). In the study of Papadakis et al. (2018), it was concluded that students were affected by internet fees and preferred low-cost internet. 
The data obtained could not be compared, since there was no previous study on job anxiety for graphic design students. However, this quantitative research can shed light on future studies and can be further developed by planning with the support of qualitative data. In addition, comparisons between universities with broader participation can be made on this subject. Promotion days can be organized both in high schools and universities in order to increase the knowledge of students about the program and profession. This study can be repeated after returning to the normal after the pandemic and the results can be compared. As a result, it can be investigated how this period, in which we are faced with restrictions, affects student psychology and responses in indoor environments at home. It can also be investigated how this period, which is at home and faced with restrictions, affects student psychology and their lives.

\section{References}

Afşar, B., \& Büyükdoğan, B. (2020). Assessments of FBAS and FSHS Students About Distance Education During the Covid-19 Pandemic Period. Karatay Sosyal Araşttrmalar Dergisi, 5, 161-182.

Ağır, F., Gür, H., \& Okçu, A. (2008). Development of the attitude scale toward distance learning: Reliability and Validity. e-Journal of New World Sciences Academy, 3(2).

Akçay, S., \& Gökçearslan, A. (2016). Grafik tasarım dersinde uzaktan eğitim yönteminin kullanımına yönelik bir uygulama ve öğrenci algıları: Gazi Üniversitesi Örneği [Perceptions of Students and an Application about the Use of Distance Education Method in Graphic Design Course: Gazi University Case]. Kastamonu Education Journal, 24(4), 1983-2004.

Aktaş, Ö., Büyüktaş, B., Gülle, M., \& Yıldız, M. (2020). Sports science students' attitudes towards distance education during isolation days caused by COVID-19 Virus. Sivas Cumhuriyet University Journal of Sport Sciences/Sivas Cumhuriyet Üniversitesi Spor Bilimleri Dergisi, 1(1), 1-9.

Almutairi, A., \& Al-Shamrani, A. (2020). Overview of COVID 19 in Children with the Current Situation in Saudi Arabia. The Egyptian Journal of Hospital Medicine (July), 80, 704-714. https://doi.org/10.21608/ejhm.2020.95617

Annur, M. F. (2020). Kesulitan Belajar; Pembelajaran Daring; Pandemi COVID-19. Paedagoria: Jurnal Kajian, Penelitian dan Pengembangan Kependidikan, 11(2), 195-201.

Antony, M. M., \& Swinson, R. P. (2000). The shyness and social anxiety workbook.

Balaman, F., \& Gelibolu, M. F. (2018). Examination of future expectations and occupational anxiety levels of pedagogical formation students. Curr Res Educ, 4(2), 86-93.

Barış, M. F. (2015) Analyzing the university students' attitudes towards distance education: Namık Kemal University Case Study. Sakarya University Journal of Education, 5(2), 36-46. https://oi.org/10.19126/suje.38758

Başaran, M., Doğan, E., Karaoğlu, E., \& Şahin, E. (2020). A Study On Effectiveness of Distance Education, As A Return of Coronavırus (Covıd-19) Pandemic Process. AJER-Academia Eğitim Araştırmaları Dergisi, 5(2), 368-397.

Becer, E. (2005). Iletişim ve Grafik Tasarım (4. Bask1). Dost Yayınları: Ankara.

Bentata, Y. (2020). COVID 2019 Pandemic: A True Digital Revolution and Birth of a New Educational Era, or an Ephemeral Phenomenon? Medical Education Online, 25, 1781378. https://doi.org/10.1080/10872981.2020.1781378

Bilgici, B. G. (2016). Okul öncesi öğretmen adaylarının mesleki kaygllarının incelenmesi [Some of Pre-School Teacher Candidates' Job Anxiety Analysis by Demographic Features] (Master's Thesis, Gazi Üniversitesi, Ankara).

Bozdam, A. (2008). Examination the occupational anxiety levels of master candidates according to some variables (Master Thesis, Selçuk University, Konya).

Bozgün, K., \& Kösterelioğlu, M. A. (2018). Öğretmen adaylarında tükenmişliğin yordayıcısı olarak mesleki kayg1 [Job anxiety as a predictor of burnout in prospective teachers]. 2. International Symposium on Innovative Approaches in Scientific Studies, SETSCI Conference Indexing System, Samsun (Volume 3, pp. 1120-1123).

Bozkurt, A. (2020). Koronavirüs (Covid-19) pandemi süreci ve pandemi sonrası dünyada eğitime yönelik değerlendirmeler: Yeni normal ve yeni eğitim paradigması. Açıöğretim Uygulamaları ve Araştırmaları Dergisi, 6(3), 112-142. Retrieved from https://dergipark.org.tr/en/pub/auad/issue/56247/773769 
Buluk, B., \& Eşitti, B. (2020). Evaluation of Distance Learning by Tourism Undergraduate Students In The Process Of Coronavirus (Covid-19). Journal of Awareness, 5(3), 285-298. https://doi.org/10.26809/joa.5.021

Büyüköztürk, Ş., Çakmak, E. K., Akgün, Ö. E., Karadeniz, Ş., \& Demirel, F. (2011). Bilimsel Araştırma Yöntemleri [Scientific Research Methods] (8th ed.). Pegem Akadem

Cabı, E., \& Yalçınalp, S. (2013). Occupational anxiety scale for prospective teachers: A study on validity and reliability. Hacettepe University Journal of Education, 44, 85-96.

Çakın, M., \& Akyavuz, E. K. (2020). Covid-19 süreci ve eğitime yansıması: Öğretmen görüşlerinin incelenmesi [The Covid-19 process and its reflection on education: An analysis on teachers' opinions]. International Journal of Social Sciences and Education Research, 6(2), 165-186. https://doi.org/10.24289/ijsser.747901

Çelik, M. (2017). Türkçe öğretmeni adaylarının kişilik özellikleri ve mesleki kaygı düzeyleri arasındaki ilişkinin incelenmesi [The relation between the occupational anxiety level and personal characteristics of turkish teacher candidates] (Master Thesis, Nevşehir Hacı Bektaş Veli University, Nevşehir). https://doi.org/10.7884/teke.4017

Çınar, B. (2018). Turizm rehberliği bölümü öğrencilerinde genel özyeterlilik alglsı, mesleki kaygı ve mesleği yapma niyeti ilişkisi [The Relationship Between General Self-Efficacy, Occupational Anxiety and Intention to Perform the Profession of Tourism Guiding Students] (Unpublished Master Thesis). Mersin Üniversitesi, Mersin. https://doi.org/10.17123/atad.656005

Coolican, M., Borras, J. C., \& Strong, M. (2020). Argentina and the COVID-19: Lessons learned from education and technical colleges in Buenos Aires Province. Journal of Education for Teaching, 46(4), 484-496. https://doi.org/10.1080/02607476.2020.1802204

Çubukçu, Z., \& Dönmez, A. (2011). The examination of the professional anxiety levels of teacher candidates. Journal of Theory and Practice in Education, 7(1), 3-25.

Deniz, S., \& Tican, C. (2017). An investigation of pre-service teachers' teacher self-efficacy beliefs and opinions for their professional anxieties. Abant İzzet Baysal Üniversitesi Ë̆itim Fakültesi Dergisi, 17(4), 1838-1859. https://doi.org/10.17240/aibuefd.2017.17.32772-363968

Drennan, J., Kennedy, J., \& Pisarski, A. (2005). Factors affecting student attitudes toward flexible online learning in management education. J. Educ. Res. 98(6), 331-338. https://doi.org/10.3200/JOER.98.6.331-338

Dursun, S., \& Karagün E. (2012). Assessment of occupational anxiety levels of preservice teachers: A research on the students in their final year at the school of physical education and sports at Kocaeli University. Kocaeli Üniversitesi Sosyal Bilimler Dergisi, 24, 93-112.

Erdas, E., Asıkuzun, E., \& Recepoğlu, E. (2017). Analyzing variables affecting the prospective preschool teachers' anxiety levels Turkish studies international periodical for the languages. Literature and History of Turkish or Turkic, 12(14), 333-356.

Ergin, A., Uzun, S. U., \& Topaloğlu, S. (2016). Future occupational anxiety and trait anxiety levels of 5th and 6th year medical students at Pamukkale University and their contributing factors. Medical Journal of Mugla Sitki Kocman University, 3(3), 16-21.

Fidan, M. (2016). Distance education students' attitudes towards distance education and their epistemological. Hacettepe University Journal of Education, 31(3), 536-550.

Firmansyah, F. (2021). Motivasi Belajar dan Respon Siswa terhadap Online Learning sebagai Strategi Pembelajaran di Masa Pandemi Covid-19. Jurnal Ilmu Pendidikan, 3(2), 589-597. https://doi.org/10.31004/edukatif.v3i2.355

Genç, M. F., \& Gümrükçüoğlu, S. (2020). The Views of Theology Faculty Students on Distance Education in the Coronavirus (Covid-19) Process. Turkish Studies, 15(4), 403-422.

Gerçek, M. (2018). The relationships between occupational anxiety and career adaptability: A study on pre-service teachers. Trakya University Journal of Social Science December, 20(2), 297-312. https://doi.org/10.26468/trakyasobed.401010

Gökmen, A., \& Ekici, G. (2018). Investigating the relationship between preservice biology teachers' perception level of teacher self-efficacy and their occupational anxiety. Anatolian Journal of Teacher, 2(2), 17-28. 
Gözler, A., Bozgeyikli, H., \& Avcı, A. (2017). The opinions of the prospective teachers taking pedagogical formation education on critical pedagogy. Abant İzzet Baysal Üniversitesi Eğitim Fakültesi Dergisi, 17(1), 189-211. https://doi.org/10.17240/aibuefd.2017.17.28551-304629

Güngör, C. (2019). The relationship between the self-efficacy, professional anxiety levels of prospective teachers (Master Thesis, Ondokuz Mayıs University, Samsun).

Güngör, C., \& Gül, İ. (2019). An investigation of pre-service teacher anxiety levels in terms of various variables: The case of Giresun province. Asian Journal of Instruction, 7(2), 74-89.

Hair, J. F., Black, W. C., Babin, B. J., Anderson, R. E., \& Tatham, R. L. (2013). Multivariate Data Analysis. Pearson Education Limited.

Hill, C., Rosehart, P., Helene, J., \& Sadhra, S. (2020). What kind of educator does the world need today? Reimagining teacher education in post-pandemic Canada. Journal of Education for Teaching, 46(4), 565-575. https://doi.org/10.1080/02607476.2020.1797439

Horney, K. (2014). Çağımızın nevrotik kişiliği (Başak Kıcır, Trans., 2nd ed.). Sel Yayıncılık.

İşman, A. (2008). Uzaktan Eğitim [Distance Education] (3. Baskı). Pegem Akademi.

Kafkas, M. E., Açak, M., Çoban, B., \& Karademir, T. (2010). Investigation of the relationship between preservice physical education teachers' sense of self-efficacy and professional concerns. Inonu University Journal of the Faculty of Education, 11(2), 93-111.

Kahraman, Ü., \& Çelik, K. (2019). The relationship between self-efficacy beliefs and professional concerns of the faculty of education formation students. Pamukkale Üniversitesi Ë̆itim Fakültesi Dergisi, 45, 353-375. https://doi.org/10.9779/PUJE.2018.237

Kara, A. (2020). The investigation of the relationship between personal properties of music teacher candidates and professional anxiety levels (Master Thesis, Atatürk Üniversitesi, Erzurum).

Karabudak, A. F. (2015). Psikoloji ilk ve son sınıf öğrencilerinin mesleki kaygılarının karşılaştırılması ve problem çözme yetisi arasındaki ilişki [Comparison of occupational anxiety and problem solving abilities between junior and senior level psychology students] (Master Thesis, Beykent Üniversitesi, İstanbul).

Karadağ, E., \& Yücel, C. (2020). Distance Education at Universities during the Novel Coronavirus Pandemic: An Analysis of Undergraduate Students' Perceptions. Journal of Higher Education (Turkey), 10(2), 181-192. https://doi.org/10.2399/yod.20.730688

Karakuş, N., Ucuzsatar, N., Karacaoğlu, M. Ö., Esendemir, N., \& Bayraktar, D. (2020). Turkish teacher candidates' views on distance. RumeliDE Journal of Language and Literature Studies, 19, 220-241.

Karatepe, F., Küçükgençay, N., \& Peker, B. (2020). What are the Perspectives of Teacher Candidates on Synchronous Distance Education? A Survey Study Journal of Social and Humanities Sciences Research, 7(53), 1262-1274. https://doi.org/10.26450/jshsr.1868

Kennerley, H. (2017). Kaygı [Anxiety] (Nur Yener, Trans., 2nd ed.). Kuraldışı Yayıncılık.

Keskin, K. (2016). İstekli olarak uzaktan eğitim yöntemiyle ders almanın akademik başarıya etkisi [The effect of academic success on taking courses as distance education as willing]. IMUCO International Multidisciplinary Conference-April 21-22 (pp. 343-349), Antalya, Turkey.

Kurnaz, E., \& Serçemeli, M. (2020). Covid-19 pandemi döneminde akademisyenlerin uzaktan eğitim ve uzaktan muhasebe eğitimine yönelik bakış açıları üzerine bir araştırma [A research on students' perspectives to distance education and distance accounting education in the covid-19 pandemic period]. International Journal of Social Sciences Academy/USBAD Uluslararast Sosyal Bilimler Akademi Dergisi, 2(3), 262-288.

Kürtüncü, M., \& Kurt, A. (2020). Problems Of Nursing Students In Distance Education In The Covid-19 Pandemia Period. Eurasian Journal of Researches in Social and Economics (EJRSE) ASEAD, 7(5), 66-77.

Kuşcalı, A. (2019). İslami ilimler fakültesi öğrencilerinin mesleki kaygı düzeylerinin çeşitli değişkenlere göre incelenmesi [Examining the Occupational Anxiety Levels of Students of Faculty of Islamic Sciences According to Certain Variables]. Aksaray University Mütefekkir, 6(11), 193-210. https://doi.org/10.30523/mutefekkir.584413

Mladenova, T., Kalmukov, Y., \& Valova, I. (2020). Covid 19-A Major Cause of Digital Transformation in Education or Just an Evaluation. Test TEM Journal, 9(3), 1163-1170. https://doi.org/10.18421/TEM93-42

Moorhouse, B. L. (2020). Adaptations to a face-to-face initial teacher education course 'forced' online due to the 
COVID-19 pandemic. Journal of Education for Teaching, 46(4), 609-611. https://doi.org/10.1080/02607476.2020.1755205

Moyo, N. (2020). Covid-19 and the future of practicum in teacher education in Zimbabwe: Rethinking the "new normal' in quality assurance for teacher certification. Journal of Education for Teaching, 46(4), 536-545. https://doi.org/10.1080/02607476.2020.1802702

Nuland, S. V., Mandzuk, D., Petrick, K. T., \& Cooper, T. (2020). COVID-19 and its effects on teacher education in Ontario: A complex adaptive systems perspective. Journal of Education for Teaching, 46(4), 442-451. https://doi.org/10.1080/02607476.2020.1802702

Osman, M. E. T. (2020). Global impact of COVID-19 on education systems: The emergency remote teaching at Sultan Qaboos University. Journal of Education for Teaching, 46(4), 463-471. https://doi.org/10.1080/02607476.2020.1802583

Özdayı, N. (2000). Eğitim fakültesinde okuyan öğrencilerin mesleki kaygılarının toplam kalite yönetimi açısından değerlendirilmesi [Evaluation of the job anxiety of students studying at the faculty of education in terms of total quality management]. M. Ü. Atatürk Faculty of Education Journal of Educational Sciences, $12,233-248$

Özdinç, S., Biçici, Y., Çamur, M., \& Turan, F. N. (2018). Determination of professional anxiety levels of undergraduate students who have physiotherapy and rehabilitation education. Journal of Higher Education and Science, 8(3), 471-479. https://doi.org/10.5961/jhes.2018.288

Papadakis, S., Kalogiannakis, M., Sifaki, E., \& Vidakis, N. (2017). Access moodle using smart mobile phones. A case study in a Greek University. In Interactivity, game creation, design, learning, and innovation (pp. 376-385). Springer, Cham. https://doi.org/10.1007/978-3-319-76908-0_36

Poultsakis, S., Papadakis, S., Kalogiannakis, M., \& Psycharis, S. (2021) The management of Digital Learning Objects of Natural Sciences and Dig- ital Experiment Simulation Tools by teachers. Advances in Mobile Learning Educational Research, 1(2), 58-71. https://doi.org/10.25082/AMLER.2021.02.002

Quezada, R. L., Talbot, C., \& Quezada-Parker, K. B. (2020). From bricks and mortar to remote teaching: A teacher education programme's response to COVID-19. Journal of Education for Teaching, 46(4), 472-483. https://doi.org/10.1080/02607476.2020.1801330

Şahin, O. (2019). Examination of the relationship between academic self-sufficiency and professional anxiety in physical education and sport teacher candidates (Master Thesis, Erciyes University, Kayseri).

Sahu, P. (2020). Closure of universities due to coronavirus disease 2019 (COVID-19): Impact on education and mental health of students and academic staff. Cureus, 12(4), e7541. https://doi.org/10.7759/cureus.7541

Sakarya, G., \& Zahal, O. (2020). The Student Opinions on Distant Violin Education During Covid-19 Epidemic. Turkish Studies, 15(6), 795-817. https://doi.org/10.7827/TurkishStudies.44504

Saracaloğlu, A. S., Kumral, O., \& Kanmaz, A. (2009). Anxieties, academic motivation levels and competencies at teaching profession of students at secondary education fields teaching. Yüzüncü Yll Üniversitesi, Eğitim Fakültesi Dergisi, 6(2), 38-54.

Sarı, H. İ. (2020). Evde kal döneminde uzaktan eğitim: Ölçme ve değerlendirmeyi neden karantinaya almamalıyı? [Distance Education in Lockdown Period: Why We Should Not Quarantine Measurement and Evaluation?]. International Journal of Scholars in Education/Uluslararası Eğitim Araştırmacıları Dergisi, 3(1), 121-128.

Sarıtaş, S. (2019). Examination of elementary teacher candidates' psychological well-being, occupational worry and self-efficacy beliefs (Master Thesis, Marmara University, İstanbul).

Şen, S. N. (2016). The analysis of the relationship between the levels of critical thinking, the abilities to show empathy and the professional concern of pre-school prospective teachers (Master Thesis, Çanakkale Onsekiz Mart University, Çanakkale).

Şenses, İ. (2019). Bilgi ve belge yönetimi bölümü ögrencileri ile tıbbi dokümantasyon ve sekreterlik programı ögrencilerini gelecekteki benzer mesleki kaygllar [Similar future occupational anxiety of information and document management department students and medical documentation and secretarial programme students] (Master Thesis, İstanbul Üniversitesi, İstanbul).

Seven, M. A. (2012) Uzaktan ve örgün eğitime devam eden öğrencilerin ingilizce dersindeki başarı düzeylerinin karşılaştırılması [Comparison of Achievement Levels in English Courses of Students Studying in Distance 
and Formal Education]. Ekev Akademi Dergisi, 16(50), 215-228.

Singh, S. (2011). Level of anxiety among prospective teachers. Shaikshik Parisamuad International Journal of Education (SPIJE), 1(1), 17-21.

Spielberger, C. D., \& Reheiser, E. C. (2009). Assessment of emotions: Anxiety, anger, depression, and curiosity. Applied Psychology: Health and Well-Being, 1(3), 271-302. https://doi.org/10.1111/j.1758-0854.2009.01017.x

T. C. Health Ministry. (2020). COVID-19 Durum Raporu [COVID-19 Status Report]. Türkiye. Retrieved from https://dosyamerkez.saglik.gov.tr/Eklenti/37778,covid-19-durum-raporupdf.pdf

Tabachnick, B. G., \& Fidell, L. S. (2013). Using Multivariate Statistics (6th ed.). Pearson, Boston.

Telli, Y. S., \& Altun, D. (2020). Coronavirüs ve çevrimiçi (Online) eğitimin önlenemeyen yükselişi [The Coronavirus and the Rising of Online Education]. Journal of University Research/Üniversite Araşttrmalart Dergisi, 3(1), 25-34. https://doi.org/10.32329/uad.711110

Traxler, J. (2018). Distance learning-predictions and possibilities. Education Sciences, 8(35), 1-13. https://doi.org/10.3390/educsci8010035

Turan, Z., \& Gürol, A. (2020). Emergency Transformation in Education: Stress Perceptions and Views of University Students Taking Online Course During the COVID-19 Pandemic HAYEF. Journal of Education, 17(2), 222-242. https://doi.org/10.5152/hayef.2020.20018

Türkdoğan, S. C. (2014). Professional concerns of preservice teachers according to their reason for choosing teaching profession (Master Thesis, Pamukkale Üniversitesi, Denizli).

Uçak, K., \& Bindak, R. (2017). Professional anxiety levels of physical education and sport teacher candidates: Ondokuz Mayis University Sample. National Journal of Sport Sciences/Ulusal Spor Bilimleri Dergisi, 1(2), 44-54. https://doi.org/10.30769/usbd.332204

Ülkü, S. (2018). İlkokullarda görev yapan ögretmenlerin uzaktan eğitime yönelik tutumları [Attitudes of primary school teachers for distance education] (Master Thesis, Abant İzzet Baysal University, Bolu).

Uludağ, G., Taşdöven, H., \& Dönmez, M. (2014). Polis adaylarının mesleki kaygı düzeylerinin çeşitli değişkenler açısından incelenmesi [Examining Occupational Anxiety Levels of Police Candidatesfrom Several Variables]. Atatürk University Journal of the Institute of Social Sciences, 18(2), 75-94.

Uluyol, Ç., \& Şahin, S. (2018). Investigation of pedagogical formation students' teaching identity and professional loss conditions. Turkey Social Studies Journal/Türkiye Sosyal Araştırmalar Dergisi, 22(3), 1051-1072.

Ünlü, H., \& Erbaş, M. K. (2018). Academic self-efficacy and occupational anxiety of physical education teacher candidates. Journal of Sports Sciences Turkey/Türkiye Spor Bilimleri Dergisi, 2(1), 15-25.

Uygun, K., Avaroğulları, M., \& Oran, M. (2016). Investigation of professional anxiety levels of social studies teacher candidates'. Turkish studies. International periodical for the languages, Literature and History of Turkish or Turkic, 11(21), 417-436.

Varol, Y. K., Erbaş, M. K., \& Ünlü, H. (2014). The predictive power of occupational anxiety levels of prospective physical education teachers upon their attitudes towards the teaching profession. Ankara University Faculty of Sport Science, 12(2), 113-123

Wang, C., Cheng, Z., Yue, X. G., \& McAleer, M. (2020). Risk management of Covid-19 by Universities in China. Journal of Risk and Financial Management, 13, 36-42. https://doi.org/10.3390/jrfm13020036

Yalman (2013). Education faculty students' levels of satisfaction with the computer-assisted distance education system (Moodle). Turkish Studies - International Periodical for the Languages, Literature and History of Turkish or Turkic, 8(8), 1395-1406.

Yavuz, R. (2016). The relationship between education faculty freshmen students' attitudes towards distance education and towards English course (Master Thesis, Abant İzzet Baysal University, Bolu).

Yenilmez, K., Balbağ, M. Z., \& Turgut, M. (2017). Investigation of prospective teachers' perceptions on distance education with respect to certain variables. Erzincan University Journal of Education Faculty, 19(2), 91-107.

Yiğit, T., Bingöl, O., Armağan, H., Çolak, R., Aruğaslan, E., Yakut, G. \& Çivril, H. (2010). Öğrenci ve Öğretim Elemanının Uzaktan Eğitime Bakış, Açısı [Viewpoints of Students and Instructors to the Distance Learning]. 
XII Academic Informatics Conference Papers/XII. Akademik Bilişim Konferansı Bildirileri, Muğla University.

Yıldırım, A. (2011). Sınıf öğretmeni adaylarının meslekî öz-yeterlik algıları ile meslekî kaygı düzeyleri arasindaki ilişkinin incelenmesi [Examining the relationship between occupational self-efficacy perceptions and job anxiety levels of elementary teacher candidates] (Master Thesis, Marmara University, Istanbul).

Yılmaz, N. A. (2020). Yükseköğretim kurumlarında Covid-19 pandemisi sürecinde uygulanan uzaktan eğitim durumu hakkında öğrencilerin tutumlarının araştırılması: Fizyoterapi ve rehabilitasyon bölümü örneği [Investigation of students' attitudes towards applied distance education in the Covid-19 pandemic process in higher education institutions: example of physiotherapy and rehabilitation department]. Necmettin Erbakan University Faculty of Health Sciences Journal/Necmettin Erbakan Üniversitesi Sağlık Bilimleri Fakültesi Dergisi, 3(1), 15-20.

\section{Copyrights}

Copyright for this article is retained by the author(s), with first publication rights granted to the journal.

This is an open-access article distributed under the terms and conditions of the Creative Commons Attribution license (http://creativecommons.org/licenses/by/4.0/). 